\title{
On the Particularism of English Landscape Archaeology
}

\author{
Matthew H. Johnson ${ }^{1}$
}

\begin{abstract}
The aim of this paper is to explore the question: why is the archaeology of English historic landscapes apparently so provincial? Inevitably the response must be that matters are more complex. In this paper, I examine the work of W. G. Hoskins, the "father of English landscape history," and draw attention to: the complex way in which landscape is embedded in nationalism; the relations between locale, province, and nation; and the way wider tensions, in particular of colonialism are embedded within Hoskins's own discourse. In conclusion, I examine ways in which this problematic continues to structure enquiry into the English landscape today and to inhibit a genuinely international and comparative approach to historic landscapes.
\end{abstract}

KEY WORDS: Hoskins; landscape; England; particularism.

"To generalise is to be an Idiot;

To particularise is the Alone Distinction of Genius"

William Blake, prefatory citation in Hoskins, Provincial England (1965)

\section{INTRODUCTION}

As an undergraduate student in the 1980 s, I became aware of two very different kinds of archaeology being practiced. Both had their own distinctive pattern of thought, manner of argument, and methods for acquiring and dealing with evidence. The first was characteristic of the "Cambridge school," whether framed in processual or postprocessual jargon. Its scope, following Grahame Clark, was explicitly global (Clark, 1977), and New Archaeology had shown us that the

${ }^{1}$ Department of Archaeology, University of Southampton, Avenue Campus, Southampton SO17 1BF, United Kingdom; e-mail: m.h.johnson@soton.ac.uk. 
purpose of archaeology was to address general, comparative questions concerning the generality of humanity, such as the origins of agriculture and the rise of states.

Many of these specific ideas, of course, were coming into question around this time. However, as much as Marxist, structural, and postprocessual perspectives questioned the scientific basis of New Archaeology, much of its global perspective was retained. Such perspectives were held to be of self-evidently international significance and scope. In time, the retention of a global perspective has been especially apparent in historical archaeology. James Deetz's hugely influential model of the Georgian Order, for example, has been used to help us understand particular contexts within a general model, the deployment of the mental blueprints of English and European culture around the world (Deetz, 1977). If we look at the prospects for a global historical archaeology, as for example articulated by Orser (1996), they are centered around concepts of colonialism and postcolonialism, the relation between text and artefact, and ideas of conflict between groups-all general categories whose utility lies in part in their potential for a global and comparative perspective.

However, many historical archaeologists working in England remain either unaware of or passively or actively hostile to such a tradition: they belong to the second category with which I rapidly became familiar. In this second form of archaeology, scholarship was about amassing and understanding particular details of material culture, landscape, and architecture for their own sake. The broader story they were to tell was either self-evident, or to be left to a future generation; and it was generally, if implicitly, conceived as a particular regional or national narrative, not as part of a global and comparative discipline. The majority of articles in journals such as Postmedieval Archaeology, the Archaeological Journal, or the Antiquaries Journal remain, superficially at least, insular in scope and particular in content; much of their role is one of "journal of record." The role of the regional and/or county journal remains an important one.

There are a range of reasons for this apparent insularity, ranging from its fit with established techniques and perceived priorities (the need to record and classify material at a local level), to the historical and organisational (the continuing importance of local and regional societies in British archaeological culture) to the ideological (I argue elsewhere that the reluctance of English and European historical archaeologists to address issues linking their nation with the wider world is in part a subconscious denial of an uncomfortable colonial past and its legacy in the present (Johnson, in press-a).

In this essay, I shall focus on one of these several reasons: the apparent insularity and particularism of one important strand of historic archaeology, namely English landscape archaeology as it is applied to historic periods, that is both the medieval and the postmedieval. I shall look at the work of W. G. Hoskins, habitually and resonantly termed the father of the English landscape tradition, and discuss the conditioning influence of Hoskins and some of his contemporaries on English landscape archaeology. I state apparent insularity, because I will argue 
that an analysis which stopped at that point would be simplistic. Underlying a surface particularism are a series of empirical and theoretical foundations to the English tradition which deserve more careful comment.

\section{AN ENGLISH FORM OF SPORT}

Perhaps the best definition of landscape archaeology is to be found in O. G. S. Crawford's classic work Archaeology in the Field (1953). Crawford outlined a form of archaeology that did not involve excavation to a great extent and concentrated on the locality and its immediate questions. His method was to start in the local Record Office: to examine the large-scale map produced by the national Ordnance Survey, and follow this by exploring both through documents and by walking across the landscape. Crawford was quite explicit that this whole method was "a modern, and primarily a British invention" and went on to suggest that field archaeology as he had defined it "is an essentially English form of sport," in part due to the presence of "persons of means, leisure, and intelligence" living in the country. It was a method that was highly local and particular in its focus-it "assumes that one has plenty of time to devote to a region that may comprise no more than two or three parishes. It is perhaps a programme more suited for a permanent resident than a temporary visitor" (Crawford, 1953, pp. 52-53, p. 208).

There are very good empirical reasons for the development of the English tradition. Crawford himself identified the presence and easy access of relevant map series and other records, and acknowledged also that the English landscape, for various historical reasons including density of settlement and its particular history of postmedieval enclosure, had palimpsest-like qualities that meant that it could be "read" or interpreted in complex ways without recourse to excavation.

Crawford's methods of field identification of historic elements of the landscape (though not his wider philosophy of archaeology; Johnson, in press-b) was adopted by a generation of landscape historians and archaeologists. W. G. Hoskins in particular, in addition to his work as an economic historian, succeeded in his "popular" books of getting an appreciation of the historic landscape of England firmly embedded in the minds of people at both academic and popular levels. His very simple message was twofold: the landscape is a lot older than often thought, and its story can be unravelled by close and careful observation of its characteristics (Hoskins, 1955, pp. 11-13).

As simple as the message was, and as reliant as it was on the methods articulated by Crawford, it was one which had an immediate theoretical component, namely particularism and localism. Hoskins quoted Blake with approval (see prefatory citation at the start of this paper), as he did habitually with Romantic writers.

I have mentioned some of the "practical" origins of this particularism in terms of field techniques; David Matless (1998) and others have traced relevant 
ideological components also (see Light, 1991, for a feminist perspective). While as an economic historian he was quite aware of the harsh realities of rural life (Hoskins, 1964), it is clear that Hoskins's view of the English landscape was a nostalgic and even sentimental one that was profoundly anti-modern in its tenor, to the extent that even his greatest fans have found it wearisome. The American writer Meinig (1979, pp. 207-208) wrote for example in an otherwise celebratory piece comparing Hoskins to JB Jackson: "We cannot avoid the conclusion that there is a deep sentimental bias laced through all his landscape writing, and while his incisive impressions of it enliven his books and vivify him in our minds as a strong and engaging personality, they also limit our confidence in his judgment and, at worst, depreciate him as an historian." However, my concern in this paper is to look behind the apparent particularism and attempt to identify deeper ideological tensions at work both in Hoskins's approach and that of English landscape archaeology more generally.

\section{IMPLICIT PERSPECTIVES}

It is a truism that the opposition in archaeological and historical thought between the particular and the general is false. To appeal to one inevitably involves the acknowledgement of the presence of another: to ask why this region or locality is "unique" presupposes some kind of generality against which that unique nature must be set. We are therefore warranted to see Hoskins's celebration of particularity in wider terms and ask: what were the deeper tensions underlying the Hoskins approach?

It is very difficult to find any explicit mention of comparative material, for example of other peasant or premodern societies, in Hoskins's writing. Hoskins's writings were copious and ranged from both scholarly and popular books to articles in the magazine The Listener and TV programmes, but some years' reading and re-reading of his books and articles on my part has yielded very little of this nature. In one of his later books, The Age of Plunder, he uses evidence from "underdeveloped countries of the modern world" to look at the number of days worked, claiming without citation: "in particularly backward areas, such as modern Sicily, labourers average only 100 days' work in a year." He also mentions the observations of the great socialist historian Richard Tawney on China (Hoskins, 1976, p. 111). Elsewhere in his work, as Phythian-Adams (1992) has observed, Hoskins has clearly been influenced by Lewis Mumford's (1934) global and comparative Technics and Civilisation, though overt references are hard if not impossible to find in his citations.

Hoskins's great theme is the medieval creation and eighteenth/nineteenthcentury dissolution of the English rural community, most vividly expressed and tabulated by his student Charles Phythian-Adams in an extract from his unpublished 
notebooks:

\begin{abstract}
I have the theme now: the old pattern of life slowly built up-describe at length-then the disintegration of the pattern, shattered beyond recognition. The old peasant tradition when mean and women were 'at home' in the world, rooted in place that had meaning and significance for them, among their own people, embedded in an ancient mode of living and conduct. They 'took care of a few fundamental things,' not nobly or beautifully perhaps, but they took care of them nevertheless. Attached to a place, and to a family and neighbours, the strongest cement a society can have. And gradually we can see the attachments being loosened, the cement crumbling, and the walls of that old society falling into ruin-the visible signs in the ruined church of St. Wistan, the silent watermill, the tumble-down cottages in the village ... (cited in Phythian Adams, 1992, p. 176).
\end{abstract}

The language Hoskins uses here is romantic and nostalgic, but the story he uses the language to tell is a familiar one. In part, it goes back to English literature in both Romantic and other genres-most obviously poems such as Oliver Goldsmith's eighteenth-century poem The Deserted Village and contemporary writing on enclosure. However, it is also dependent on wider historical models.

The ideas that Hoskins implicitly used to understand the transition between medieval and modern was already there, part of the ambience of $1930 \mathrm{~s}-1950 \mathrm{~s}$ culture and intellectual life. In English scholarship, Richard Tawney had written about the transformation of rural England, the "rise of the gentry" and the development of capitalism and an urban bourgeoisie in the sixteenth and seventeenth centuries (Tawney, 1941). The 1940s had seen an extensive literature on the rise of the middle classes and of the yeomanry in particular (Campbell, 1942; see Barry and Brooks, 1994, for a more recent discussion of this theme). By the 1950s the work of a new generation of Marxist historians was interpreting the English Civil War of the 1640s as the English Revolution, a bourgeois revolution that created the preconditions for the further development of a capitalist economy and society (for example Hill, 1964). In short, Hoskins's nostalgic preference for particularities and his contemporaries' stress on a generalising, Marxist model of history were very different from one another, but they were interdependent-superficially like chalk and cheese in their language and tone, at a deeper level they fitted like lock and key.

One of the criticisms of the Hill thesis of the English Civil War as a bourgeois revolution is especially pertinent here. The class interpretation of the English revolution tended to view England as an insular unit, whose history was driven forward by its own internal dynamic. However, by 1600 (and indeed well before) no discussion of English society and politics could be disentangled from that of the other three nations-Wales, Scotland and Ireland-that in different ways were politically connected to England. Revisionist scholarship, moving away from an exclusively class-based interpretation, focused in part on the way political events in one nation triggered off crisis in another, most obviously when the revolt of the Scottish Kirk against Charles's policies meant that he had to call an English 
Parliament raise funds in England for an army, a Parliament that he found unable to control (Morrill, 1993).

References to Wales, Scotland and Ireland are close to absent from Hoskins's work. The elision that the reader will have noted in Crawford's language between "Britain" and "England" is here absent_because Hoskins makes almost no reference to "Britain" at all. Hoskins is drawing here on traditions of English Romanticism, and on a deeper well of English political and cultural sentiment that links a rejection of modernity with a rejection of what are perceived as the "Celtic fringes" and even implicitly of the union of the three or four kingdoms into "Great Britain" in the first place. As a result, analysis of the historical processes through which English, Welsh, Scottish and in part Irish identities were to become articulated within a common conception of Britishness (discussed most recently and critically by Colley, 1992; see also Johnson, 2003) was entirely bypassed in the work both of Hoskins and of his contemporaries in landscape archaeology.

As a result, one critical route within which a more generalising and comparative view of landscape archaeology, not to mention a view in which questions of conflict, power and inequality would be more effectively foregrounded, was lost. At different historic periods, English forms of landscape have been imposed on other parts of the British Isles, and in their turn have been resisted in different ways. A landscape history and archaeology of the four nations of England, Wales, Scotland, and Ireland would include, among other episodes: the thirteenth-century imposition of royal castles and new towns in north Wales; the subsequent Tudor division of Wales into English shires; plantations and attempted reorganisations of different regions of Ireland such as Munster and Ulster from the later sixteenth century onwards; the reorganisation of Scottish agriculture culminating in the Highland Clearances; and local and "native" rebellion and resistance to all these episodes. These episodes are not merely the subject of fashionable postcolonial discourse; they were part of the traditional history of the British Isles taught to most British schoolchildren before the fragmentation of history teaching in the 1980s.

The first edition Ordnance Survey maps, so central as research tools to the field methods of landscape archaeology, were after all the direct descendants of map series drawn up for explicitly military and political reasons (to help the army to control the Scottish Highlands in the face of Jacobite resistance; Bermingham, 2000). It would have been increasingly difficult for Hoskins to endorse Blake's insistence on particularism, then, had he taken on the task of placing his work on England into the context of understanding wider British landscapes. The continuing ambiguity and elision between ideas of England and of Britain allowed him to do so, and his intellectual home within a long-standing tradition of English Romanticism which failed to engage with these larger questions, enabled him to do so. 


\section{COLONIALISM}

Edward Said's $(1978,1993)$ thinking on postcolonialism and literature showed how revealing it was to look for the silences in both scholarly and literary works, and developed the idea that the silences were often more revealing than what was actually there. It is interesting that one of the examples he used was a classic piece of literature on English landscape-Jane Austen's Mansfield Park, where the order and civilisation of the park and estate and that of its inhabitants is financed by the colonial miseries of the developing British Empire, and the sugar plantations in Antigua in particular. Following Said, we can argue that behind Hoskins's localism and particularism lies a series of silences that are in their own way quite eloquent.

Reading Hoskins's work, it is almost impossible for the reader to discern that many of the dynamics of the transformation of the English landscape were bound up with contexts outside the bounds of provincial England. The seventeenth century saw steady mass migration to the American colonies; in the late eighteenth and nineteenth centuries, around 160,000 convicts were transported to Australia, most never to return (Hughes, 1986). The demographic and social impact on Hoskins's England of both immigration and transportation, not to mention the political impact ("politicals" made up a small minority of those transported, but the effect in terms of transferring dissidence and radicalism to the other wide of the world was major) are almost never discussed or alluded to. I have only been able to find one such reference, a characteristically autobiographical and emotive passage:

\footnotetext{
My ancestors were men and women of no particular eminence even in local history, farmers nearly all of them until the collapse of local communities all over England in the early 19th century drove them off the land and into the towns and across the water to the American continent. But they were the sort of people who form the foundations of any stable society. (Hoskins 1954, pp. xix-xx).
}

Hoskins seem to have had an aversion to prisons: in his Devon (1954) he gives the great prison at Princetown in Dartmoor only the most cursory treatment, where other discussions of the moor, including H. V. Morton's nostalgic and conservative In Search of England (1927) give it much more importance.

More broadly, the development of Hoskins's provincial England, the articulation of distinct provincial identities and localities within a nation-state, was by definition bound up with the wider colonial world. The colonies provided the markets for the goods produced by the Industrial Revolution he bemoans; his beloved yeoman ancestors puffed on pipes filled with Virginia and Carolina tobacco.

Again, concern with such themes is not new. The most extreme example of the articulation of the traditional England so loved by Hoskins and its wider place in the world must be the Eric Williams (1944) thesis on the interrelationship between 
capitalism and slavery. Williams argued that the development of capitalism in eighteenth-century England was very directly dependent on the proceeds of the sugar plantations of the Caribbean. Williams's thesis was published in 1944 and provoked a major and continuing debate in academic circles; it is impossible to believe that Hoskins was unaware of Williams's work. And yet, while the clear implication of Williams was that the Georgian parks and gardens of the English countryside were funded through wealth produced through the miseries of enslaved men and women, I have not been able to find a single reference to the Williams thesis in Hoskins's work. This is surely a most profound and revealing silence.

There are three ways in which we might interpret this silence. The first is taken by Kathleen Biddick (1993) when she draws attention to Hoskins's characterisation of a much earlier period, the early middle ages. Hoskins talked frequently, most notably in The Making of the English Landscape (1955, pp. 45-74) of early Anglo-Saxon settlers clearing the "primeval forest" and "making homes" for themselves. She asks: "to what voice, to what gaze, to what desire does this passage refer?" (Biddick, 1993, p. 24). Biddick is implying that a postcolonial analysis of scholarship on medieval landscapes might start with the way a colonial ideology has been inscribed into the origin myths of the Anglo-Saxons themselves.

The second reaction might be to view Hoskins's whole project as a reaction against forces which a later generation would characterize in terms of globalisation, late capitalism modernity, what you will. David Matless (1998) has drawn attention to one passage in which Hoskins readily admits his particularizing approach, and justifies it with reference to the need to provide a sense of rootedness for people. Hoskins even made the suggestion that Rutland, that most provincial and smallscale of English counties be set aside as a Human Conservancy Area. In this sense, Hoskins's project should not be judged in analytical terms as a failure to grasp colonial dynamics, but rather should be treated as a story or even as an origin myth for the English, one of a series of narratives told to provide an understanding of locality and community at a time when those ideas are under threat. The more famous myth of this kind is of course that created by J. R. R Tolkein, whose Lord of the Rings was a self-conscious attempt to write an origin myth for the English; the moral and political evaluation of both Tolkein's and Hoskins's stories are of course up for debate (Curry, 1998).

A third reaction is to focus more clearly on who this story is being told for. Hoskins's Provincial England (1965) occupies a particular ideological space. In one sense, to use postcolonial jargon, it is outside the metropole. Hoskins himself, after all, was an outsider in the British establishment. He came from relatively humble, lower-middle-class origins and took his degree at his home town of Exeter rather than Oxford or Cambridge. When in later life he became Reader in Economic History at Oxford, he was never happy there, spent much of 
his time away and eventually moved back to Exeter. He also hated London, which he identified with mindless modern bureaucracy (Johnson, in press-b).

Much of the subsequent development of landscape archaeology, particularly for historic periods, does not find an easy place in the academic pinnacles of the metropole. Its audiences are extra-mural and continuing education classes; I have already observed that its concerns stand at a distance from the grand global and even imperialistic traditions of Cambridge archaeology. Indeed, Hoskins's narrative stands at some distance from the great national stories of Maitland, Trevelyan and others, to the extent that it is not even mentioned in Peter Mandler's (2002) highly metropolitan discussion of history and British national life.

\section{HOSKINS'S LEGACY AND THE FUTURE}

Many postmedieval and historical archaeologists, including myself, were inspired by Hoskins's passion for the English landscape, and learnt from the Hoskins/Crawford tradition how to go about understanding the landscape that we saw around us. Hoskins remains a truly great figure with a lasting legacy. It is clear from the discussion above that his legacy cannot be continued wholesale and uncritically, but equally it cannot be rejected.

Contemporary historical archaeologists working within the English landscape tradition face two challenges. In the current political climate, with the grading used in the Research Assessment Exercise (used in the past to determine the level of Government funding of universities) explicitly linked to the production of work of "international quality," it behoves the university-based researcher to demonstrate precisely why work in the Hoskins tradition merits this description. More extended reflection on the relationship between region, nation, and the world beyond should be a primary component of this reflection. The "Leicester school" of local historians have already engaged in this task (Phythian-Adams, 1993; see also Tranter et al., 1999) but historical archaeologists have yet to catch up.

The second challenge is a political one. Hoskins's England is a place many of us including this author hold in great affection, but it is a place that has hitherto largely the preserve of white, middle-class people. (It is interesting that while Hoskins was politically engaged-he was a Liberal councillor in Exeter for a few years-I cannot find reference in his writings to working-class appropriations of the landscape such as the Kinder Mass Trespass; he repeats Wordsworth's aversion to the masses when he wrote that making the landscape too widely known would destroy its beauty [Hoskins 1954, p. 285]). The Chair of the Commission for Racial Equality, Trevor Philips (2004) has spoken of the danger of "a kind of passive apartheid" in the English countryside. If we accept that our scholarship is in any way reflexive, our work should be addressing that passive apartheid, for example by restoring stories of movement and exile to the English landscape (Bender and Winer, 2001). 


\section{CONCLUSION}

Many readers of this article, particularly those from outside Anglophone countries, may wonder why the writings of one landscape historian are of such especial relevance in understanding the intellectual trajectory of British postmedieval and historical archaeology. The answer is partly that Hoskins was one of a generation of scholars working with such assumptions; his writing is the best known and the most colorful, and he had the greatest impact in a wider intellectual sense. Other scholars of that generation include the historian Maurice Beresford and the archaeologist John Hurst, jointly responsible for the influential excavation and research of the deserted medieval village of Wharram Percy (Beresford and Hurst, 1990). Hoskins is routinely cited as an "ancestor figure": he got the Leicester School of local history established (Phythian-Adams, 1992) and is cited in prefatory manner by, among others, Mick Aston (2002), Della Hooke (2000), and Joan Thirsk (2000), all of whom clearly regard Hoskins as an "ancestor figure."

From the work of Hoskins and his contemporaries, then, sprang a tradition of archaeological enquiry into the English landscape whose method as applied to historic periods, described by O. G. S. Crawford, continues largely unmodified in its theoretical approach and broader ideology largely to this day. Prehistoric archaeologists took the Hoskins/Crawford method of identifying landscape elements in the field, but instead of tying them to a moral or historical story, were prompted by these identifications to ask broadly processual questions: what social forms produced these "ritual landscapes"? What environmental conditions lay behind these field systems? As a result, there have been great intellectual developments in prehistoric landscape archaeology (Bradley, 1993, 1998; Thomas, 2004), and more arguably in the "Leicester School" of landscape history (Phythian-Adams, 1993). However, much of the intellectual and theoretical basis of the study of medieval villages, of the field systems around them, and of enclosure, remains largely unchanged. If we take as an example recent work on medieval villages Hoskins would have been interested in the new findings, but the methods (with the possible exception of environmental archaeology) and the wider discursive frame (the accumulation of particular stories or anecdotes into a portrait of a region) would have been entirely familiar to him.

This analysis is offered as a contribution to an ongoing debate about the contribution of English traditions of archaeology and history to a world historical archaeology. In this sense, it amplifies earlier comments I have made about the relationship between global processes and particular local circumstances (Johnson, 1999). There, I was critical of certain trends within world historical archaeology, cautioning against what I saw as a "flattening-out" of local cultures and particularities in an effort to fit their stories into a straitjacket. In this paper, I have tried to trace some elements of a reverse pattern: where a Romantic attachment to foregrounding the particularities of place has been shown to lead to an elision 
and silence over the articulation of English localities and provinces with the wider world, and in particular the genesis and development of colonial relationships.

I want to conclude by repeating that the analysis above is not offered as a condemnation or refutation of Hoskins's work. It is an attempt to think through the issues surrounding a possible future for the Hoskins tradition. If those of us working within it really love that tradition and feel it is worth preserving, we have to address its flaws and silences, and make it relevant to the twenty-first century.

\section{ACKNOWLEDGMENTS}

I thank two anonymous reviewers for comments which, I hope, greatly improved the arguments here.

\section{REFERENCES CITED}

Aston, M. (2002). Interpreting the Landscape From the Air, Tempus, Stroud.

Barry, J., and Brooks, C. (eds.) (1994). The Middling Sort of People: Culture, Society and Politics in England, 1550-1800, Macmillan, Basingstoke.

Bender, B., and Winer, M. (eds.) (2001). Contested Landscapes: Movement, Exile and Place, Berg, Oxford.

Beresford, M. W., and Hurst, J. G. (eds.) (1990). Wharram Percy: Deserted Medieval Village, Batsford,

Bermingham, A. (2000). Learning to Draw: Studies in the Cultural History of a Polite and Useful Art, Yale University Press, New Haven.

Biddick, K. (1993). Decolonizing the English past: Readings in medieval archaeology and history. Journal of British Studies 32: 1-24.

Bradley, R. (1993). Altering the Earth: The Origins of Monuments in Britain and Continental Europe, Society of Antiquaries of Scotland, Edinburgh, UK

Bradley, R. (1998). The Significance of Monuments: On The Shaping of Human Experience in Neolithic and Bronze Age Europe, Routledge, London. Campbell, M. (1942). The English Yeoman Under the Tudors and Early Stuarts, Yale University Press,
New Haven, CT.

Clark, G. (1977). World Prehistory: In New Perspective, Cambridge University Press, Cambridge, UK.

Colley, L. (1992). Britons: Forging the Nation 1707-1837, Yale University Press, New Haven, CT.

Crawford, O. G. S. (1953). Archaeology in the Field, Phoenix House, London.

Curry, P. (1998). Defending Middle-Earth: Tolkein, Myth, and Modernity, HarperCollins, London. Deetz, J. F. (1977). In Small Things Forgotten: An Archaeology of Early American Life, Anchor,
New York.

Hill, C. (1964). Society and Puritanism in Pre-Revolutionary England, Secker and Warburg, London.

Hooke, D. (ed.) (2000). Landscape: The Richest Historical Record. SLS Supplementary Series 1, Society for Landscape Studies, Amesbury.

Hoskins, W. G. (1954). Devon, Collins, London.

Hoskins, W. G. (1955). The Making of the English Landscape, Hodder and Stoughton, London.

Hoskins, W. G. (1964). Harvest and hunger. The Listener 72: 931-932. Hoskins, W. G. (1965). Provincial England: Essays in Social and Economic History, Macmillan,
London. Hughes, R. (1986). The Fatal Shore: A History of the Transportation of Convicts to Australia, 1787-
I868, Collins, London.

Johnson, M. H. (1999). Rethinking historical archaeology. In Funari, P., Hall, M., and Jones, S. (eds.), Historical Archaeology: Back From the Edge, Routledge, London, pp. 23-36. 
Johnson, M. H. (2003). Muffling inclusiveness: Some notes towards an archacology of the British. In Lawrence, S. (ed.), Archaeologies of the British: Explorations of Identity in Great Britain and its Colonies, 1600-1945, Routledge, London, pp. 17-30.

Johnson, M. H. (in press-a). The tide reversed: An historical archaeology of Europe. In Hall, M., and Silliman, S. (eds.), Historical Archaeology, Routledge, London.

Johnson, M. H. (in press-b). Ideas of Landscape, Blackwell, Oxford.

Light, A. (1991). Forever England: Femininity, Conservatism, and Literature Between the Wars, Routledge, London.

Mandler, P. (2002). History and National Life, Profile, London.

Matless, D. (1998). Landscape and Englishness, Reaktion, London.

Meinig, D. W. (1979). Reading the landscape: An appreciation of W. G. Hoskins and J. B. Jackson. In Meinig, D. W. (ed.), The Interpretation of Ordinary Landscapes: Geographical Essays, Oxford University Press, Oxford, pp. 195-244.

Morrill, J. (1993). The Nature of the English Revolution: Essays, Longman, London.

Morton, H. V. (1927). In Search of England, Methuen, London.

Mumford, L. (1934). Technics and Civilization, Routledge, London.

Orser, C. (1996). An Historical Archaeology of the Modern World, Plenum, New York.

Philips, T. (2004). Ethnic Minorities in Rural Areas, Unpublished press release, Commission for Racial Equality, October 8.

Phythian-Adams, C. (1992). Hoskins's England: A local historian of genius and the realization of his theme. Local Historian 22(4): 170-183.

Phythian-Adams, C. (1993). Societies, Cultures, and Kinship, 1580-1850: Cultural Provinces and English Local History, Leicester University Press, Leicester, UK.

Said, E. (1978). Orientalism: Western Conceptions of the Orient, Penguin, Harmondsworth.

Said, E. (1993). Culture and Imperialism, Chatto and Windus, Harmondsworth.

Tawney, R. (1941). The rise of the gentry, 1558-1640. Economic History Review 11: 1-38.

Thirsk, J. (ed.) (2000). The English Rural Landscape, Oxford University Press, Oxford.

Thomas, J. (2004). Archaeology and Modernity, Routledge, London.

Tranter, M., Hawker, K., Rowley, J., and Thompson, M. (eds.) (1999). English Local History: The Leicester Approach. A Departmental Bibliography and History, 1948-1998, Friends of the Department of English Local History, Leicester, UK.

Williams, E. (1944). Capitalism and Slavery, University of North Carolina Press, Chapel Hill. 